\title{
Redescription of Derallus strigipennis Orchymont, 1940 (Coleoptera: Hydrophilidae), new records and a key to species of Derallus Sharp 1882
}

\author{
Adriana OLIVA \\ Museo Argentino de Ciencias Naturales «Bernardino Rivadavia», Av. A. Gallardo 470, \\ C1405DJR Buenos Aires, Argentina. E-mail: aoliva@macn.gov.ar
}

\begin{abstract}
The type of Derallus strigipennis Orchymont, 1940 is redescribed and figured. New records are given for three other species of the genus: D.ambitus Orchymont, 1940 from Ecuador, D.argutus Orchymont, 1940 from Argentina and Bolivia, and D. intermedius Oliva 1995 from Bolivia and Guyana. A key to the described species is given.
\end{abstract}

Key words: Aquatic Coleoptera, Hydrophilidae, Neotropical fauna.

Resumen: Redescripción de Derallus strigipennis Orchymont, 1940 (Coleoptera: Hydrophilidae), nuevos registros y clave para las especies de Derallus Sharp 1882. Se redescribe e ilustra el tipo de Derallus strigipennis Orchymont, 1940. Se citan nuevos registros para otras tres especies del género: D. ambitus Orchymont, 1940 de Ecuador, D.argutus Orchymont, 1940 de Argentina y Bolivia, y D. intermedius Oliva 1995 de Bolivia y Guyana. Se presenta una clave para las especies descriptas.

Palabras clave: Coleópteros acuáticos, Hydrophilidae, Fauna neotropical.

\section{INTRODUCTION}

The Hydrophilidae belonging to the tribe Berosini are characterized by the presence of swimming hairs on the middle and hind tibiae and by the long, narrow scutellum (Hansen, 1991). Berosini are represented by three genera in the Neotropical Region. The genus Derallus Sharp 1882, established for D. angustus Sharp, 1882 from Guatemala, is characterized by the very convex, laterally compressed body with shining black dorsal parts, protibiae broadened towards the apex and weakly prominent eyes (Sharp, 1882). The genus Derallus also differs from Hemiosus Sharp 1887 and Berosus Leach 1817 by the effaced humeral humps, the absence of intercalar striae and the short maxillary palpi (not longer than $1 / 2$ of the head width) (Oliva, 1989). Both Sharp (1882) and Hansen (1991) have overlooked the absence of an intercalar stria, because the sculpture of the elytral disk is often obsolete in individuals of $D$. angustus. The species of Derallus have 7-segmented antennae and five apparent urosternites, differing in this from the genera Regimbartia Zaitzev, 1908 and Allocotocoerus Kraatz, 1883, not found in America (Hansen, 1991). The male genitalia are depressed, with basal piece symmetrical at base and simple distal pieces. The genus comprises 15 species of Neotropical distribution (Hansen, 1999), all of them small (2-5 mm in length), very convex beetles with deeply melanic, glossy dorsum. There is no sexual dimorfism. The elytra bear ten rows of punctures which at least in some species have a complex structure (Oliva 1992, figs. $66,72,77)$.

Makhan (2005) described three new species of Derallus from Suriname. However, the descriptions and illustrations do not allow recognition of the species, which must therefore be treated as species dubiae. On the subject of Makhan's incursions into the taxonomy of Coleoptera, see Coleopterologische Rundschau 77 (2007): 38; 60; $88 ; 146$.

\section{MATERIAL AND METHODS}

This paper is the result of two visits made by the author in 2009 to the Institut Royal des Sciences Naturelles de Belgique (Brussels, Belgium) and to the Division of Entomology of the University of Kansas (Lawrence, USA).

The material in every case consisted of pinned beetles. Morphological characters were studied under microscope. When needed, the specimens were relaxed in hot water. Both optical and electron microphotographies of the type specimen of D. strigipennis were taken. 


\section{RESULTS}

Key to the species of Derallus

1 - Shape angular, in dorsal aspect pronotum narrowed in front and humeral humps prominent, in lateral aspect pronotum, frons and clypeus raised. Frons strongly carinate. Dorsal sculpture coarse, dense, punctures contiguous. Mesosternal process wide, hollow. Ventral surface of femora with numerous spine-like hairs. Male genitalia: basal piece slightly less than half of total length. Paramera rounded at apex. Median lobe a little longer than paramera (Brazil: Amazonas).

D. perpunctatus Oliva, 1984

1'- Shape smooth, in dorsal aspect oval, without humeral humps, in lateral aspect the dorsum describing a single curve. Frons not, or very finely, carinate. Dorsal sculpture moderate to fine, punctures not contiguous except on elytral striae. Mesosternal process laminar, if partly hollow, narrow. Ventral surface of the femora with a few minute spine-like hairs ................ 2

2 - Shape compressed: in anterior aspect the outer elytral interstriae appear vertical. Disk of pronotum and of elytra often smooth, if punctate punctures fine and shallow. Elytra with the four outer striae grooved. Mesosternal process in the shape of a thick lamina, with the ventral edge forming three acute teeth, the middle one longer. Metasternal process thickly carinate, the carina reaching the posterior edge. Male genitalia with median lobe shorter than the paramera, which are gradually narrowed, narrowly rounded at the apex, taken together spindle-shaped

2'- Shape not compressed. Elytra with inner striae nearly as deep as the outer ones; if the outer striae are distinctly grooved, only the two outer ones are so. Mesosternal process not tridentate. Metasternal process finely carinate, the carina usually ending at the base of the posterior angle of the process. Median lobe longer than the paramera; if shorter, paramera not regularly narrowed 4

3 - Size moderate (length 2.2-2.9 mm). Shape short: ratio length/height around 1.60. Male genitalia with basal piece about half of total length (S USA to northern half of Argentina; abundant; often in ephemeral habitats) D. angustus Sharp, 1882

3'- Size large (length 2.9-3.2 mm). Shape elongate: ratio length/height 1.65 or more. Male genitalia with basal piece about 3/5 of total length (Brazil: Amazonas; Pernambuco; R. Janeiro) D. anicatus Orchymont, 1940

4 - Elytral sculpture regular, with all the striae bearing well-impressed punctures, which are only a little larger on the outer striae. Interstriae bearing punctures $1 / 3$ to $1 / 4$ of the size of those of striae . .5

4'- Elytral sculpture markedly coarser and deeper on the outer elytral striae .......................... 9

5 - Size small (length around $2.2 \mathrm{~mm}$ ). Mesosternal process small, either with anterior tooth more prominent than posterior one, or with a rounded posterior angle more prominent than anterior tooth and thickened into a pair of bumps. Male genitalia with basal piece a little shorter than the distal ones, median lobe much longer than the paramera..... 6

5 '- Size large (length more than $2.5 \mathrm{~mm}$ ). If posterior angle of mesosternal process is more prominent than anterior tooth, it is rounded, not divided into a pair of bumps ... 7

6 - Mesosternal process with acute anterior tooth and a pair of blunt bumps more strongly raised than the tooth. Paramera broad, rounded outwards and angular on the inner apical portion (Amazonia: Brazil, Venezuela) D. terraenovae Oliva, 1984

6'-Mesosternal process strongly raised, laminar for the most part, with the free ventral edge emarginated into two teeth, the anterior one more prominent, the posterior one weakly thickened. Paramera truncate, forming outwards a rounded obtuse angle, inwards a straight angle 1981 (Parana basin: Argentina, Paraguay, S Bolivia, Brazil: M. Grosso) D. paranensis Oliva,

7 - Mesosternal process laminar, shaped as a parallelogram ..................................................... 8

7'- Mesosternal process with a small anterior tooth and a rounded posterior angle ................... 9 
8 - Dorsal sculpture deep, well-impressed, only a little finer towards the ends of the elytra. Head and pronotum densely punctured. Elytral striae reaching the elytral apex. Interstriae with bior triseriate punctures, about $1 / 3$ of the serial punctures. Male genitalia: basal piece long, about $3 / 5$ of total length. Paramera abruptly acuminate at distal $1 / 3$, the narrowed parts divergent, rounded ar the apices. Median lobe distinctly shorter than paramera (Argentina; Uruguay) ..... D. argentinensis Bruch, 1915

8'- Dorsal sculpture fine and shallow, Head and pronotum finely and sparsely punctate. Outer elytral striae interrupted on the posterior $1 / 4$ of the elytron. Interstriae with fine punctures, many of them bearing long whitish hairs. Male genitalia: basal piece moderately long, hardly more than half of total length. Paramera taken together broadly spindleshaped, apices narrowly rounded. Median lobe distinctly shorter than paramera (Amazonia: Brazil) D. pectoralis Oliva, 1984

9 - Dorsal sculpture very fine and shallow, moderately dense. Mesosternal process with curved anterior tooth, behind this a straight edge, posterior angle rounded, hollow, less strongly raised than anterior tooth. First apparent urosternite with a carina that does not reach the posterior margin. Male genitalia: basal piece long, about 3/5 of total length. Paramera taken together spindle-shaped, apices narrowly rounded, weakly directed inwards. Median lobe a little longer than the paramera (N Argentina; S Bolivia; Brazil; Paraguay).

D. argutus Orchymont, 1940

9'- Dorsal sculpture fine and dense. Mesosternal process with a small anterior tooth, immediately followed by the rounded, hollow posterior angle, which is more strongly raised than the anterior tooth. First urosternite carinate in its whole length. Male genitalia: basal piece short, about 2/5 of total length. Paramera taken together broadly spindle-shaped, each one abruptly narrowed at apical 1/5, the narrowed portions straight, rounded at apex (Brazil: Minas Gerais; Guyana) D. intermedius Oliva, 1995

10 - Mesosternal process very short and very strongly raised, either without distinct anterior tooth or with posterior part not rounded. 11

10'- Mesosternal process small, weakly raised, with a laminar anterior tooth and a hollowed posterior part, in lateral aspect rounded, more prominent than the anterior tooth ........... 13

11 - Size large (length of holotype $2.9 \mathrm{~mm}$ ), shape globular. Elytra with the two outer striae sunken into grooves in short stretches, the interstriae between them convex. Mesosternal process with anterior angle not quite tooth-like and a rounded posterior projection. First urosternite with a thick, strongly raised carina. Male genitalia: paramera rounded at apex; median lobe distinctly shorter than paramera (Brazil: Parana) ............................... D. strigipennis Orchymont, 1940

11'- Size moderate. Shape elongate, if short, not globular. Elytral interstriae not convex ....... 12

12 - Length 2.0-2.5 mm. Shape short, convex. Outer elytral stria sunken into a groove on middle third of its length. Elytral interstriae not raised. Mesosternal process shaped as a very short parallelogram, the anterior angle not produced, the posterior angle much more strongly raised than the anterior one. First urosternite with a fine carina that does not reach the posterior margin. Male genitalia: basal piece rather longer than half of total length. Paramera broadly rounded at apex. Median lobe much shorter than paramera (Amazonian Brazil; Guyana) ................................................................................... D. subglobosus Oliva, 1984

12'- Shape elongate. Pronotal disk sparsely, but distinctly punctate. Outer elytral striae with greatly enlarged, contiguous punctures on the middle $1 / 3$ of striae $8^{\text {th }}, 9^{\text {th }}$ and $10^{\text {th }}$, also on a small median stretch of the 7th. Inner striae with smaller punctures, spaced by less than their diameter, giving an appearance of grooves. Outer elytral interstriae raised but not convex. Interstria $10^{\text {th }}$ with uni- or biseriated punctures, about $1 / 2$ the size of punctures on striae. Mesosternal process with anterior tooth, less prominent than the rounded posterior angle. Metasternal carina fine, long. Carina on $1^{\text {st }}$ apparent urosternite fine, not reaching the posterior edge. Basal piece about $2 / 3$ of total length, but produced distally into a pair of struts; including the latter, the basal piece comprises $3 / 4$ of total length. Paramera broadly truncate at the apex. Median lobe much shorter than paramera (Central America) D. rudis Sharp, 1887 
13 - Elytral striae reduced to rows of shallow punctures. Mesosternal process excavated into a semicircle between the anterior tooth and the rounded, much more prominent posterior angle. First apparent urosternite carinate in its whole length. Male genitalia: basal piece about $3 / 5$ of total length. Paramera very short, broadened and rounded at apices. Median lobe shorter than the paramera (Brazil: Amazonas) D. brachyphallus Oliva, 1984

13' - Elytral striae distinctly marked, if reduced to rows of punctures, the latter are large and deep. 14

14 - Interstria 10th with bi- or triseriated punctures. Mesosternal process in ventral aspect narrowly triangular, in lateral aspect very short. Metasternal process with carina not reaching the posterior angle. First apparent urosternite with carina hardly reaching the posterior margin, strongly raised in anterior half. Shape moderately short and broad. Length/width ratio: 1.62, length/height ratio: 1.82 (lectotype). Male genitalia: basal piece very short, about $1 \frac{1 / 2}{2}$ times as long as wide, $2 / 5$ of total length. Paramera distally rounded, weakly angular inwards. Median lobe distinctly longer than the paramera (from southern USA to N Argentina; never abundant save in some samples from Venezuela) D. altus LeConte

14 ' - Interestria 10th with uniseriated punctures. Mesosternal process in the shape of a moderately broad triangle, in lateral aspect moderately short. Metasternal process reaching the base of the posterior angle. First urosternite with carina strongly raised between the metacoxae, behind broadened and lowered, merging with the sternite before reaching the posterior margin of the latter. Mesofemora with basal pubescence extended, convex towards the femoral apex. Male genitalia: basal piece a little less than half of total length, twice as long as wide. Paramera spindle-shaped, narrowly rounded at apices. Median lobe a little longer than the paramera (Tropical and Subtropical South America to N Argentina) D. ambitus Orchymont, 1940

\section{Derallus strigipennis Orchymont, 1940}

1940 Orchymont Derallus strigipennis, Bull. Ann. Soc. Ent. Belgique 80: 196-197.

Holotype and only known specimen in the collection of the Institut Royal des Sciences Naturelles de Belgique (Brussels, Belgium). The type, a male, was glued to a card in dorsal aspect, with the abdomen and male genitalia dissected and glued to the card. I detached the insect and re-glued it with Arabic gum in lateral aspect to allow observation of sternal characters. However, I did not dare relax the unique specimen to reposition the legs. Therefore, the mesosternal process is not easy to observe.

Labels: A d'Orchymont det/ Derallus/ strigipennis m.// Brasilien Parana/ S. E. Lagoa VIII 1 (male).

\section{Redescription}

Size large (length $2.9 \mathrm{~mm}$ ). Shape high (height $2.0 \mathrm{~mm}$ ), globular, not compressed. Length/height ratio: 1.45 .

Dorsal sculpture thick, shallow. Head and pronotum finely punctate. The two outer series of punctures sunken into striae on the posterior half of the elytron, the interstriae between them strongly convex (Fig. 1). Elsewhere all interstriae flat and striae marked only by larger punctures. Punctures on outer interstriae about $2 / 3$ of strial punctures. The SEM images show a single sensillum-bearing puncture, slightly excentrical to the large sunken area (Fig. 2). In D. altus each sensillum is placed in a small deep puncture with two equidistant accessory punctures; in $D$. ambitus there is a single accessory puncture; in $D$. angustus there are three, placed in a triangle with the setigerous puncture in the centre (Oliva, 1992).

Mesosternal process thickly laminar, short, prominent, with the ventral edge produced, rounded, more prominent than the small anterior tooth. First urosternite with a thick, strongly raised carina which reaches the posterior edge.

Male genitalia: basal piece about as long as distal ones (Fig. 3). Paramera lanceolate, with rounded apices. Median lobe shorter than paramera.

This species ressembles $D$. subglobosus Oliva 1984 , but it is larger (2.9 $\mathrm{mm}$ as opposed to 2.0 $2.5 \mathrm{~mm}$ ), with the two outer rows of elytral punctures sunken into grooves at least in part of their length and with the interstriae between them convex. The mesosternal process is rounded ventrally, whereas it is truncate in $D$. subglobosus. Note: in Oliva 1984 the numbers on plate II are mistaken. № 5 should read $6(D$. anicatus) and no 6 should read 5 (D. subglobosus). 


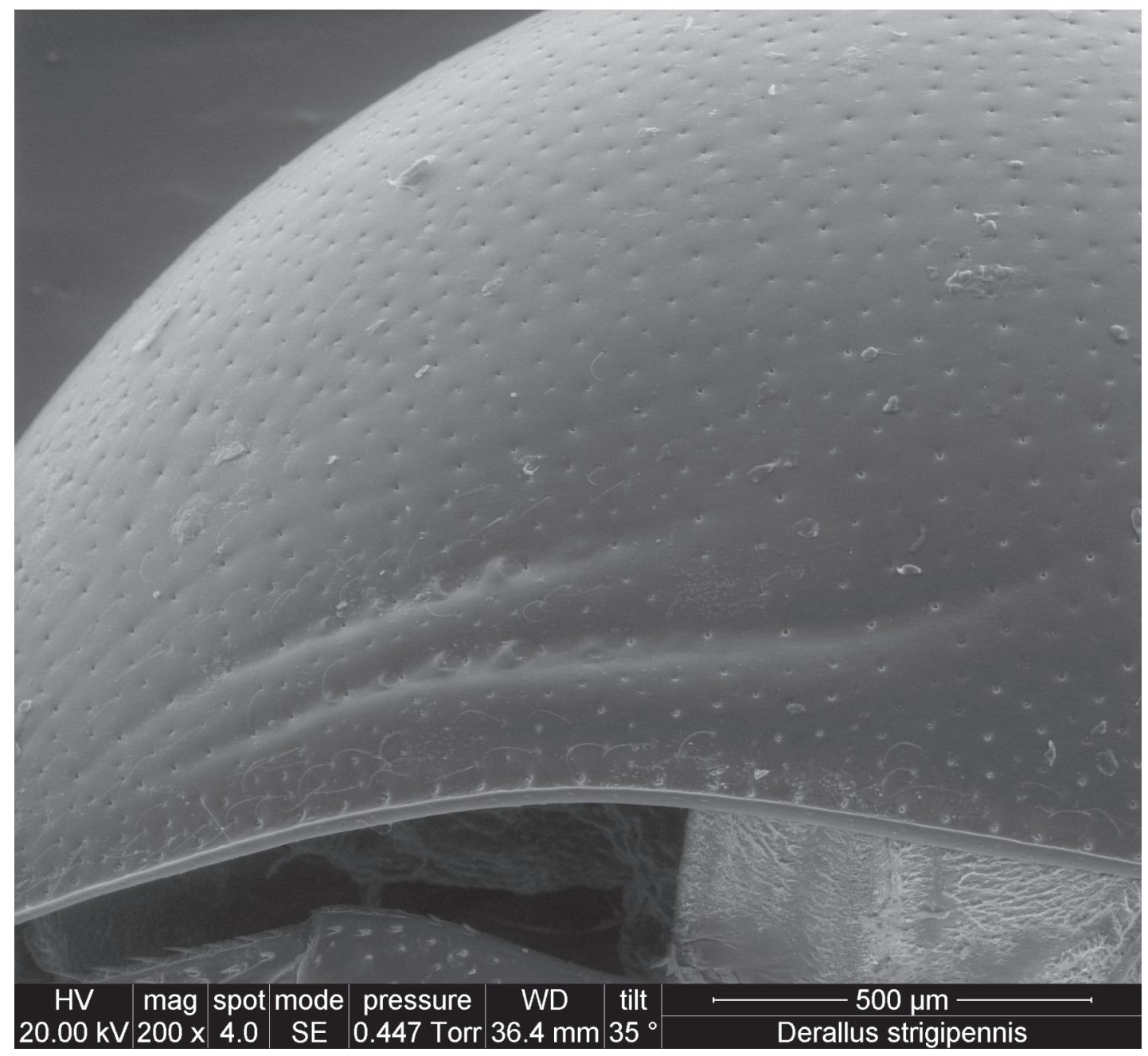

Fig. 1. Derallus strigipennis Orchymont, 1940. Elytra in lateral aspect. 200 x.

\section{New records}

Derallus ambitus Orchymont, 1940

«Ecuador, Prov. Napo (14)/1.8 km SW/ ARCHIDONA/2005' 'W 77048'23''/580 m, 22.xi.2006/M. Fikaèek \& J.Skuhrovec legt.” Small series ex coll. M. Fikaèek.

Described from Brazil: Pernambuco. Also in NE Argentina and Uruguay (Oliva, 1981)

\section{Derallus argutus Orchymont, 1940}

«ARGENTINA bor. 2004/CHACO Prov., 97 $\mathrm{km}$ NW/of RESISTENCIA, $10 \mathrm{~km} / \mathrm{W}$ of Capitán Solari, 3-7-ii/26웅'32'S 59³6'29' W/coll. Fikaèek". 2 specimens ex coll. M. Fikaèek, which he kindly donated for the collection of the Museo argentino de Ciencias naturales.

«Bolivia/Santa Cruz district/nr. Buena Vista. Hotel Flora and/Fauna, 22-26-OCT-2002/Morris \& Wauper colls». Seven specimens in the Univ. of Kansas.
Described from Brazil: Pernambuco. Recorded from Paraguay: Vallemí (Oliva, 1981).

Derallus intermedius Oliva, 1995

«Bolivia/Santa Cruz district/nr. Buena Vista. Hotel Flora and/Fauna, 22-26-OCT-2002/Morris \& Wauper colls». Seven specimens in the Univ. of Kansas.

Guyana: Mazaruni-Potaro/Takutu Mountains $/ 6^{\circ} 15^{\prime} \mathrm{N}, 5^{\circ} 5^{\prime}$ 'W, 10 xii. 1984/leg. P.D. Perkins, from sifted stream debris». A single specimen in the UK.

Described from Brazil: Minas Gerais: Buritis, Ribeirao Confins.

\section{CONCLUSIONS}

\section{Distribution of the species of Derallus}

Of the 15 species described, only $D$. rudis Sharp, 1887, appears to be absent from South 


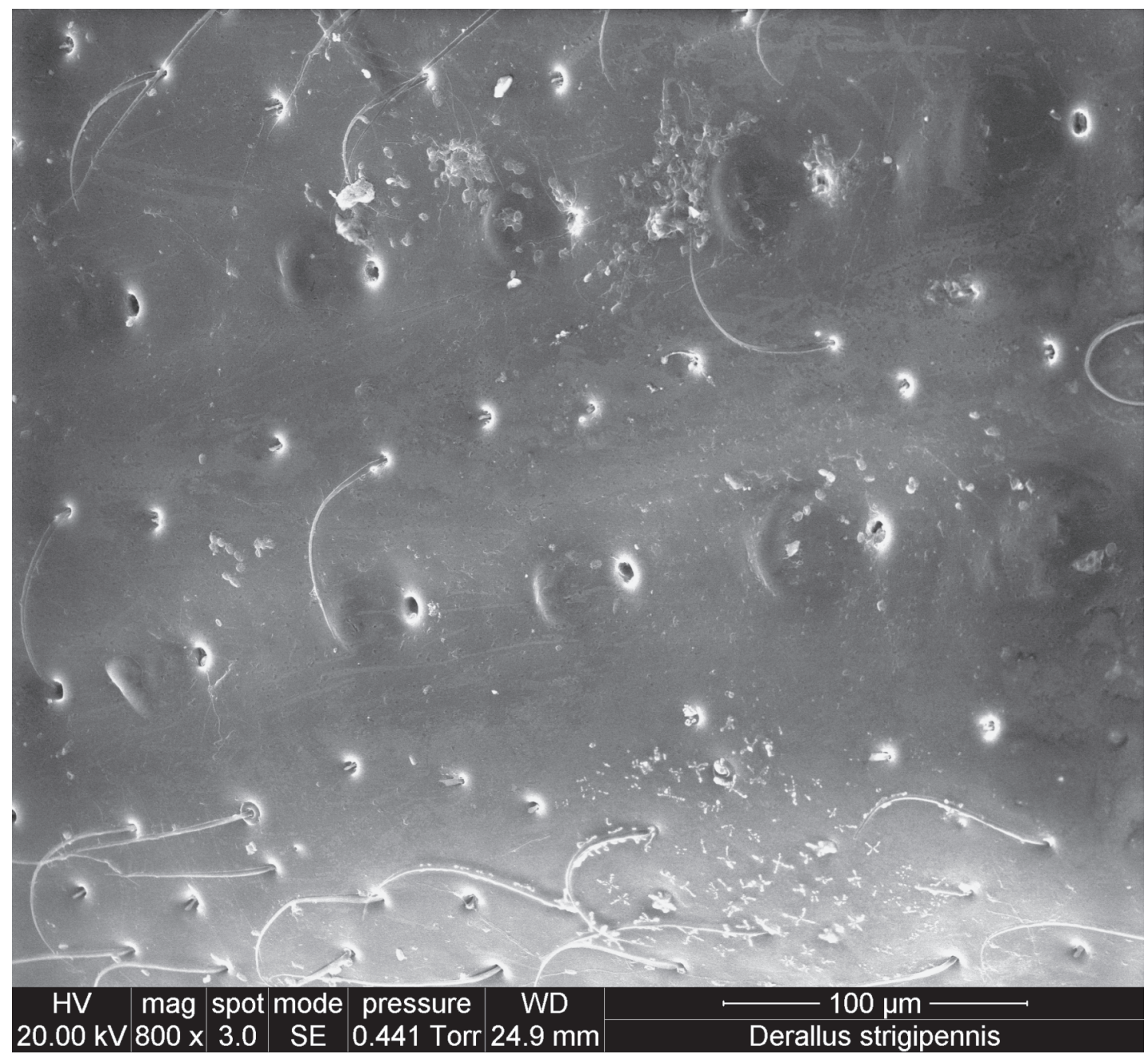

Fig. 2. D. strigipennis. Detail of elytral punctures. $800 \mathrm{x}$.

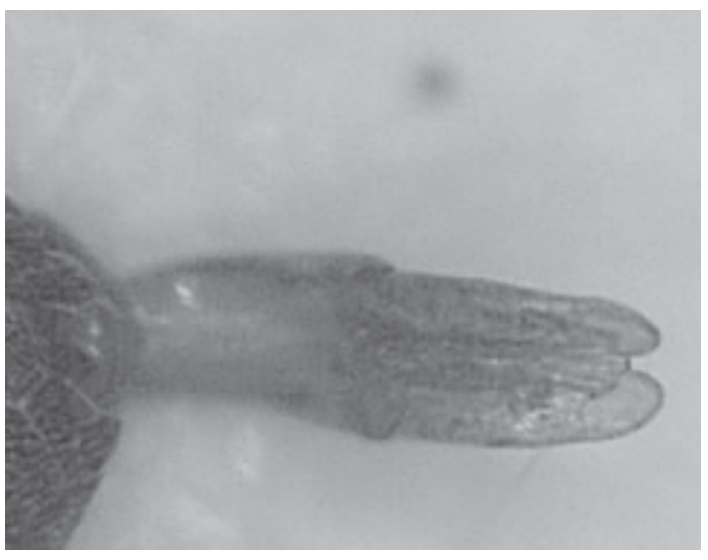

Fig. 3: D. strigipennis. Male genitalia in tergal view. $100 \mathrm{x}$.

America. Two species (D. altus and D. angustus) extend from southern North America to tropical and subtropical South America; the latter has been found as far south as Sierra de la Ventana, Buenos Aires Province, Argentina. The remaining species are distinctly South-American in distribution.

Six species are recorded for Argentina; of these, $D$. angustus, $D$. argentinensis and $D$. paranensis have been collected from many localities along the Paraná basin, while $D$. altus, $D$. ambitus and $D$. argutus present few records in the north of the country. Brazil has the greatest diversity, with 10 species described from Brazilian localities. Some of these species have an Amazonian distribution, and they have been collected in countries adjacent to Brazil, but always upon the Amazonas basin.

\section{ACKNOWLEDGEMENTS}

This paper was written as part of the author's work as researcher of CONICET (Consejo 
nacional de Investigaciones científicas y tecnológicas), Argentina. I thank Ms. Isabelle Sauvage and Ms. Michelle Van Aasche of the IRSNB for their help, Dr. Jerôme Constant for the optical photograph and Lic. Jullien Cillis for the SEM photographs. I also thank Dr. Martin Fikacek for communicating the specimens of $D$. argutus.

\section{BIBLIOGRAPHY}

Hansen, M. 1991. The Hydrophiloid beetles. Phylogeny, classification and a revision of the genera (Coleoptera, Hydrophiloidea). Biol. Skr. Kong. Danske Vidensk. Selsk. 40: 1-367.

- 1999. World Catalogue of Insects, 2: Hydrophiloidea (s. str) Coleoptera. Apollo Books, Amsterdam, 416 pp.
Oliva, A. 1981. El género Derallus Sharp en la Argentina (Coleoptera, Hydrophilidae). Revista de la Sociedad entomológica argentina 40(1-4): 285-296.

- 1984. Derallus de la cuenca del Amazonas (Coleoptera, Hydrophilidae). Revista de la Sociedad entomológica argentina 42 (1-4): 343-351.

- 1989. El género Berosus Sharp en América del Sur. Revista del Museo argentino de Ciencias naturales (Buenos Aires, Argentina) (Entomología) 6(4): 57-235.

- 1992. Cuticular microstructure in some genera of Hydrophiloidea (Coleoptera) and their phylogenetic significance. Bulletin de l'Institut Royal des Sciences Naturelles de Belgique, Entomologie, 62: 33-56.

- 1995. Novedades sobre Derallus (Coleoptera; Hydrophilidae). Physis (Buenos Aires), secc. B, 50 (118-119): 1-3.

Orchymont, A. 1940. Contribution à l'étude des Palpicornia (XIV). Bulletin et Annales de la Societé d' Entomologie de Belgique 80: 157-197.

Sharp, D. 1882. Biologia Centrali-Americana: Coleoptera 1(2): 1-824. 